\title{
Trophic state evaluation for selected lakes in Yellowstone National Park, USA
}

\author{
A. W. Miller \\ Department of Civil \& Environmental Engineering, \\ Brigham Young University, USA
}

\begin{abstract}
The purpose of this study is to classify the trophic state for selected lakes in Yellowstone National Park, USA. This paper also documents that monitoring methods and perspectives used in this study meet current acceptable practices. For selected lakes in Yellowstone National Park, phosphorus, nitrogen, chlorophyll-a, and other lake characteristics are studied to identify lake behavior and to classify the annual average trophic state of the lakes. The four main trophic states are oligotrophic, mesotrophic, eutrophic and hyper-eutrophic. The greater the trophic state, the greater the level of eutrophication that has taken place. Eutrophication is the natural aging process of a lake as it progresses from clear and pristine deep water to more shallow, turbid, and nutrient rich water where plant life and algae are more abundant. The trophic state of a lake is a measurement of where the lake is along the eutrophication process. Human interaction tends to speed up eutrophication by introducing accelerated loadings of nitrogen and phosphorus into aquatic systems. As lakes advance in the eutrophication process, water quality generally decreases. Four models are used in this study to classify the trophic state of the lakes: the Carlson Trophic State Index, the Vollenweider Model, the Larsen-Mercier Model, and the Nitrogen-Phosphorus Ratio Model. Simple models are commonly used where steady-state conditions and lake homogeneity are assumed. There is concern that natural processes and human activity on and around the Yellowstone Lakes are causing the water quality to decline. The objectives of this study are to identify possible areas of concern and develop a baseline to which future evaluations can be compared. This paper presents results for some 20 lakes in Yellowstone Park, which have been studied over the past 12 years.
\end{abstract}

Keywords: trophic state, lake water quality, eutrophication, phosphorus, chlorophyll-a, Secchi depth, modeling. 


\section{Introduction}

The purpose of this study was to classify the trophic state for selected lakes in Yellowstone National Park, USA. This paper also documents the study monitoring methods and perspectives as meeting current acceptable practice.

For selected lakes in Yellowstone National Park, phosphorus, nitrogen, chlorophyll-a, and other lake characteristics were studied to identify short-term lake behavior and to classify the annual average trophic state of the lakes. By studying short-term lake behavior, there may be a greater understanding of how the trophic state of a lake can be averaged annually.

There is concern that natural processes and human activity on and around the lakes are causing the water quality to decline. We were unable to find any previous studies that defined the trophic state of the lakes. Therefore, an objective of this study is to evaluate the current trophic state of the lakes and develop a preliminary baseline to which future evaluations can be compared.

This study has provided a benchmark trophic state survey not only for comparison to future evaluations, but to identify possible areas of concern. The greater the trophic state, the greater the eutrophication that has taken place. As lakes advance in the eutrophication process, water quality generally decreases.

\section{Eutrophication}

Eutrophication is the natural aging process of a lake as it progresses from clear and pristine deep water, that does not support much plant or animal life, to more shallow, turbid, and nutrient rich water where plant life and algae is abundant. This process occurs in all lakes happening over thousands of years, and Chapra [1] says the eventual end is the filling of the lake with sediments and formation of a meadow. Human interaction tends to speed up the eutrophication process by adding accelerated loadings of nitrogen and phosphorus into aquatic systems. The trophic state of a lake is a measurement of where the lake is in the eutrophication process. Tchobanoglous and Schroeder [2] give the four states explained below.

\subsection{Trophic states}

Oligotrophic: The water is clear and devoid of most plants and algae because there are not many nutrients such as nitrogen and phosphorus found in the water. Mesotrophic: Plant and animal life is abundant and diverse in all forms and in all levels of the food chain.

Eutrophic: The water quality is poor but there still exists an abundance of life. However, there are fewer species and these species are usually of lower quality. In addition, there are more algal blooms and slime as well as algal turbidity. Hyper-eutrophic: The water quality is exceptionally poor with an overabundance of algae. Animal life is similar to eutrophic state in that there are fewer species. 


\subsection{Nutrients and algae}

Nutrients found in the water are the fuel of the eutrophication process.

Phosphorus and nitrogen are particularly important since they stimulate plant and algae growth. Phosphorus and nitrogen enter a wilderness area lake in various ways. One is by leaching from the subsurface bedrock into groundwater that eventually flows into the lake. Another is by tributaries eroding soil and carrying the sediment as well as material from the forest floor into the lake. Animal waste in or around the lake can contribute to the inflow of phosphorus and nitrogen as can human activity. Trash or other waste can enter the lake directly, while hiking or other activities can cause more erosion of the soil which enters the tributaries and ultimately the lake. The human acceleration of the eutrophication process is commonly called cultural eutrophication [1].

Phosphorus concentrations and algae levels in a lake can fluctuate markedly over time. Comparison of short-term results to annual averages may give insight as to a lake's response to nutrients and how longer-term eutrophication may be progressing. During the growing season or summer, growth is nurtured by a rise in water temperature. Phosphorus is used by algae and is typically depleted significantly during summer months. Phosphorus concentrations and algae may be increased by storms, which cause mixing and contribute phosphorus loads from eroded soils in the watershed. NALMS [3] states some of this phosphorus and nitrogen is available to algae in the photic zone and triggers algae growth.

For this study, one focus was the correlation of trophic state and algae growth. Algae in lakes can be seen and therefore is often of concern by lake users. A national survey in 1998 showed that 44\% of all U.S. lakes contained excessive nutrients that contribute to aquatic growth, especially algae. Data and information on algae growth can help to explain short-term variations in lake water nutrient levels and hence trophic state [3].

\section{Trophic state indicators}

Four widely used trophic state indicators are the Secchi disk transparency, chlorophyll-a levels, total phosphorus and nitrogen. Typically these parameters are all measured and compared to provide valuable information about the relationship among water nutrients and algal growth. The parameters together provide a more complete picture, than if one or more is not included. US EPA [4] guidelines encourage using all four of these indicators.

\subsection{Transparency}

Secchi disk transparency measures water clarity. Transparency reduces as algal populations grow. The Secchi disk is the most commonly used parameter in monitoring programs. Microorganisms other than algae, suspended sediments, and other dissolved materials that color the water can effect Secchi disk measurements. In some shallow lakes, a Secchi disk reading will be inaccurate if the disk reaches the bottom before disappearing from site [4]. 


\subsection{Chlorophyll-a}

Chlorophyll-a, contained in most algae, is a photosynthetic pigment in the algal cells. Different algal species produce differing amounts of chlorophyll-a. Two lakes can have the same amount of chlorophyll-a, but one have more algae because of a difference in algae species. Chlorophyll-a increases during the day and decreases at night, and is changed significantly by seasons. The exact amount of algae cannot be determined from the amount of chlorophyll-a, but it is still one of the best "simple" indicators of algal biomass [4].

\subsection{Phosphorus}

Phosphorus is a measurement of water fertility, is rapidly used by algae, and hence is often found in low concentrations. Other forms of phosphorus are more dynamic and convert over time to orthophosphate. Lakes are tested for total phosphorus [4]. For eutrophication analysis, total phosphorus is generally the single most important nutrient to determine when lakes are phosphorus limited [3]. Because phosphorus tends to remain bound to soil particles, drainage from eroded soils carries higher amounts of phosphorus than from vegetated soils. Similarly, surface runoff yields higher concentrations of total phosphorus than infiltration water according to Harper [5]. Particulate phosphorus may be deposited in bottom sediments, where much of it is acted upon by micro-bacteria and ultimately converted into dissolved orthophosphate according to Correll [6].

\section{Sampling methods}

Samples were taken in 1 liter bottles and fixed with sulfuric acid. Inlet and inlake samples were analyzed for total phosphorus, and in-lake samples were also analyzed for chlorophyll-a and nitrogen. Sampling was in one or more locations at each lake, and also in the inlets and outlets, and was consistent from lake to lake for comparison. Sampling was every one or two months over the spring to fall seasons when lakes were accessible. Information on field forms included human and animal activity and estimates of the Secchi depth and stream flow.

\section{Trophic state models}

Three models were used in this study to classify the trophic state of the lakes; the Carlson Trophic State Index Model, the Vollenweider Model, and the LarsenMercier Model. Simple models are used where steady-state conditions and lake homogeneity are assumed. Furthermore, the models are spatially and temporally averaged. These assumptions are reasonable for the lakes in this study because these lakes are generally small and well mixed. Models with these assumptions are commonly used because they still make useful predictions [3].

\subsection{Carlson trophic state index}

Carlson's Model utilizes the measurements of three water quality characteristics to graphically estimate an average trophic state. See figure 1 as an example. The 


\section{Carlson's Trophic State Index}

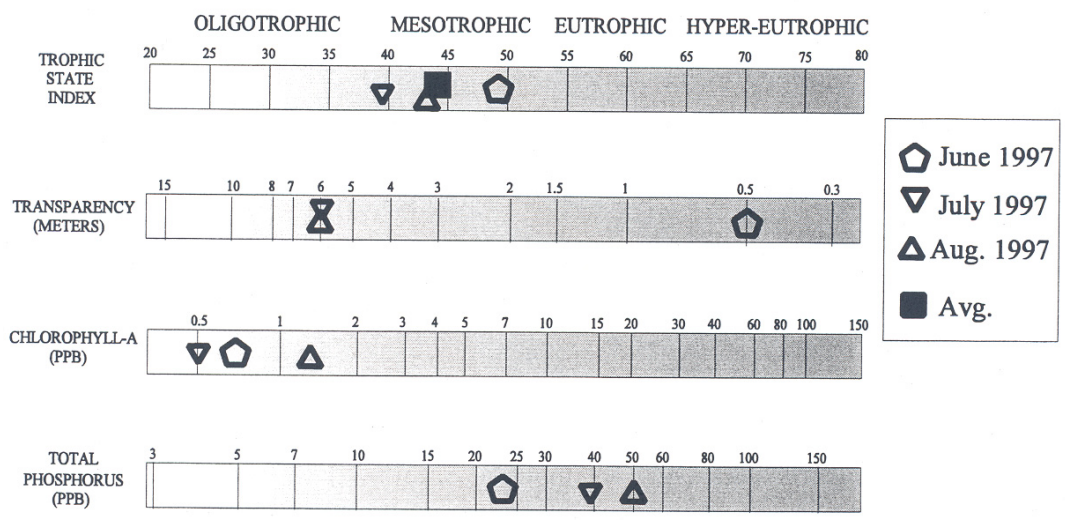

Figure 1: $\quad$ Example of the Carlson model.

Table 1: General trophic states and their sub-states.

\begin{tabular}{|c|c|c|c|c|c|c|c|c|}
\hline \multicolumn{3}{|c|}{ Oligotrophic } & \multicolumn{3}{c|}{ Mesotrophic } & \multicolumn{3}{c|}{ Eutrophic } \\
\hline $\begin{array}{c}\text { Strong } \\
\text { Oligo }\end{array}$ & Oligo & $\begin{array}{l}\text { Slight } \\
\text { Oligo }\end{array}$ & $\begin{array}{c}\text { Slight } \\
\text { Meso }\end{array}$ & Meso & $\begin{array}{c}\text { Strong } \\
\text { Meso }\end{array}$ & $\begin{array}{c}\text { Slight } \\
\text { Eutro }\end{array}$ & Eutro & $\begin{array}{c}\text { Strong } \\
\text { Eutro }\end{array}$ \\
\hline$<26$ & $26-33$ & $33-38$ & $38-43$ & $43-49$ & $49-54$ & $54-58$ & $58-62$ & $>62$ \\
\hline
\end{tabular}

three measurements are transparency, chlorophyll-a, and total phosphorus concentration in the lake. Each measured value is plotted on a logarithmic scale specific to the measured parameter. Carlson [7] says that based upon the value's location, an average can be found that describes the trophic state. Carlson Trophic State Index (TSI) is the most widely used trophic state indicator and is commonly used in lake protection and restoration [3]. Sampling measurements are applied to the following TSI equations to determine TSI values [3]:

TSI $($ Secchi disk $)=60-14.41 * \ln ($ depth in meters $)$

TSI $($ chlorophyll-a) $=30.6+9.81 * \ln ($ concentration in $\mathrm{ug} / \mathrm{L})$

TSI (total phosphorus) $=4.15+14.42 * \ln ($ concentration in $\mathrm{ug} / \mathrm{L})$

Usually TSI values are classified as follows: mesotrophic at $38<=$ TSI $<=54$, eutrophic at TSI $>54$ and oligotrophic at TSI $<38$ [4]. We subdivided the TSI values for a finer classification of the trophic states, as shown in table 1 . The Carlson phosphorus TSI is generally valid for phosphorus limited lakes. TSI results for the individual parameters may not be close to the same values if unique conditions exist. For example, a growth of zooplankton may suppress the algae, lowering the chlorophyll-a, while the TSI for phosphorus remains high.

\subsection{Vollenweider model}

The Vollenweider Model utilizes measurements of total inflowing phosphorus concentration plotted against the hydraulic residence time of the lake. The 


\section{VOLLENWEIDER'S MODEL}

\section{Phosphorus Loading Diagram}

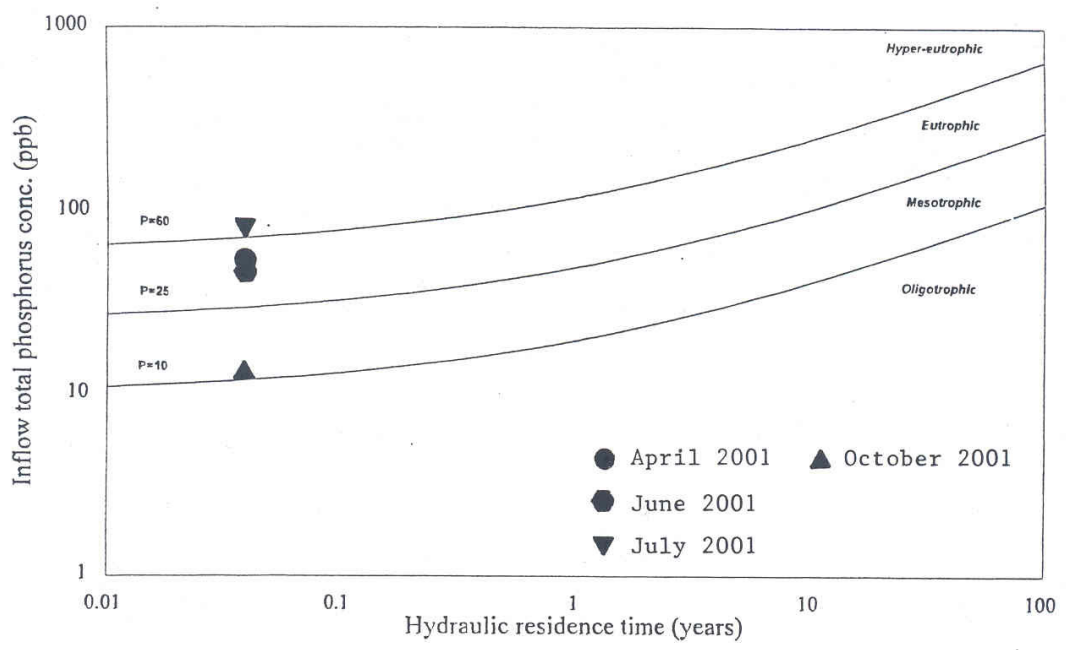

Figure 2: $\quad$ Example of the Vollenweider model.

hydraulic residence time is the average outflow divided into the volume of the lake. Vollenweider [8] states that the location of the values on the graph determines the trophic state of the lake. See Figure 2 as an example.

\subsection{Larsen-Mercier model}

The Larsen-Mercier Model [9] uses measurements of the total inflowing phosphorus concentration plotted against the phosphorus retention coefficient.

See figure 3 as an example. This phosphorus retention coefficient is calculated by the following equation:

$$
\text { Phosphorus Retention Coefficient }=\frac{P_{I N} Q_{I N}-P_{\text {OUT }} Q_{\text {OUT }}}{P_{I N} Q_{I N}}
$$

where: $\mathrm{P}_{\mathrm{IN}}=$ total phosphorus concentration in the inflow

$\mathrm{Q}_{\mathrm{IN}}=$ flow rate of the incoming water

$\mathrm{P}_{\text {OUT }}=$ total phosphorus concentration in the outflow

Q

In this model, sometimes the average phosphorus concentration in the lake water was used for the outflow phosphorus concentration. This is an appropriate assumption for small, well-mixed lakes that typically have small hydraulic residence times, but may not be for larger lakes with longer residence times.

\section{Large lakes in south Yellowstone Park}

This paper presents the trophic state results for large lakes in south Yellowstone Park, namely, Shoshone Lake, Lewis Lake and Heart Lake as shown on figure 4. 


\section{LARSEN MERCIER MODEL Phosphorus Loading Diagram}

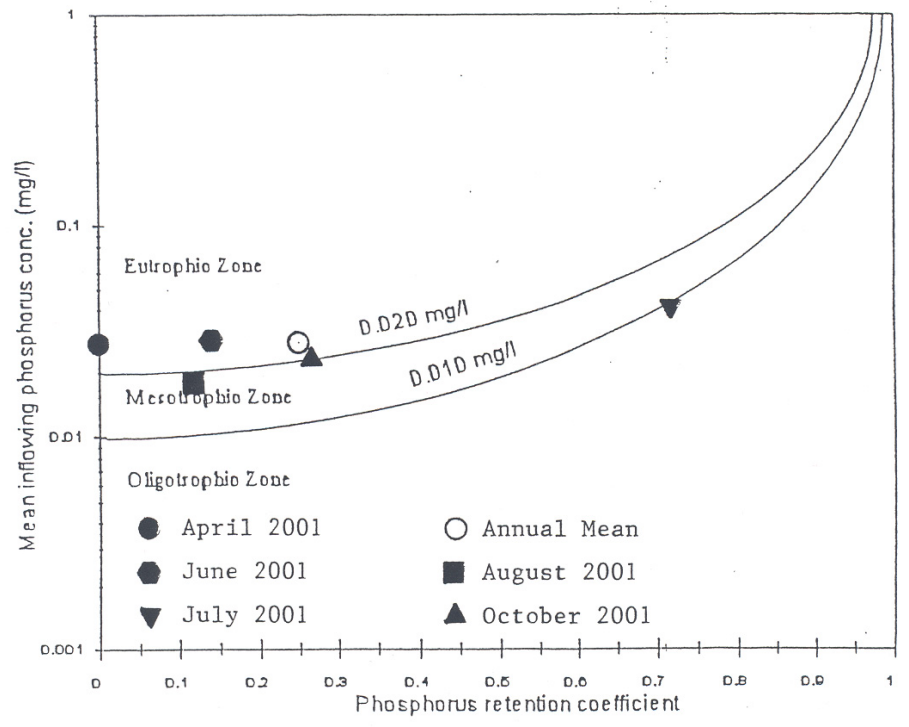

Figure 3: Example of the Larsen-Mercier model.

\subsection{Shoshone Lake}

Shoshone Lake is approximately 6 miles $(10 \mathrm{~km})$ southwest of Yellowstone Lake (see figure 4). The elevation is $7791 \mathrm{ft}(2375 \mathrm{~m})$ and the depth is $200 \mathrm{ft}(61 \mathrm{~m})$. The surface area is approximately 8100 acres $\left(32.8 \mathrm{~km}^{2}\right)$ and the approximate volume is 778,000 acre- $\mathrm{ft}\left(0.96 \mathrm{~km}^{3}\right)$. Shoshone Lake has three main tributaries; DeLacy, Shoshone and Moose Creeks. Lewis River is the only outlet of the lake.

Water samples were taken from the lake at three different locations; from the northeast side of the lake near DeLacy Creek, from the west side near Shoshone Creek, and from the southeast side near the Lewis River outlet. The results of the model analyses over the summer months show that Shoshone Lake is mesotrophic at DeLacy Creek and slightly oligotrophic at both Shoshone Creek and near the outlet. The lake as a whole is classified as slightly mesotrophic (see table 2). DeLacy Creek and the lake near DeLacy Creek are a concern because of their high phosphorus concentration and trophic state, respectively.

\subsection{Lewis Lake}

Lewis Lake, at elevation of 7,779 $\mathrm{ft}(2371 \mathrm{~m})$, is about 3 miles $(5 \mathrm{~km})$ southeast of Shoshone Lake (see figure 4). It has a surface area of 2,700 acres $\left(10.9 \mathrm{~km}^{2}\right)$ and an approximate volume of 121,000 acre-ft $\left(0.15 \mathrm{~km}^{3}\right)$. The depth is $100 \mathrm{ft}$ $(30 \mathrm{~m})$ at the center, but in the western quarter the depth is no more than $10 \mathrm{ft}(3 \mathrm{~m})$. 


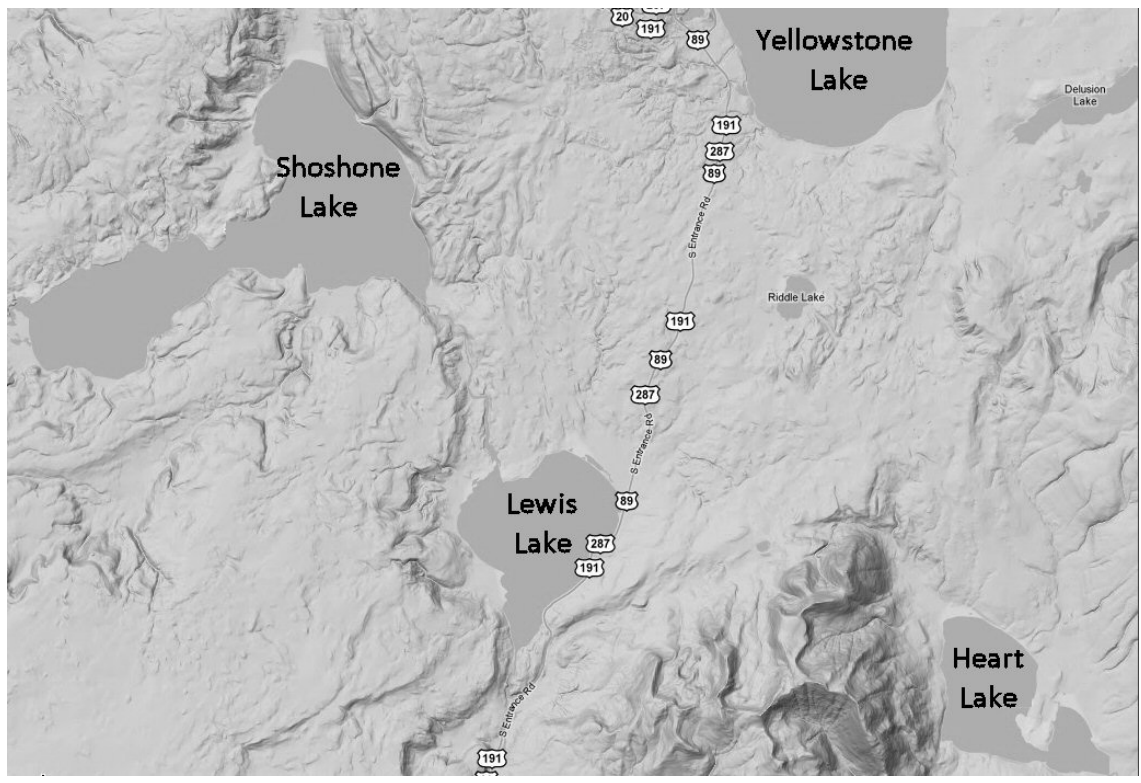

Figure 4: $\quad$ Map of large lakes in south Yellowstone Park.

Table 2: $\quad$ Large lakes' trophic states according to the three models.

\begin{tabular}{|c|c|}
\hline Model & Classification \\
\hline Shoshone Lake & \\
Carlson & Slightly Mesotrophic \\
Vollenweider & Slightly Mesotrophic \\
Larsen-Mercier & Mesotrophic \\
Shoshone Lake Average & Slightly Mesotrophic \\
\hline Lewis Lake & Slightly Mesotrophic \\
Carlson & Slightly Mesotrophic \\
Vollenweider & Slightly Mesotrophic \\
Larsen-Mercier & Slightly Mesotrophic \\
Lewis Lake Average & \\
\hline Heart Lake & Slightly Oligotrophic \\
Carlson & Slightly Oligotrophic \\
Vollenweider & Mesotrophic \\
Larsen-Mercier & Slightly Mesotrophic \\
\hline Heart Lake Average &
\end{tabular}

The main inlets to the lake are Lewis River and Dogshead Creek. The only outlet is the Lewis River at the south end of the lake.

Sampling results show that Lewis Lake is mesotrophic in the northeast at Dogshead Creek and slightly mesotrophic in both the south and in the northwest near the inlet. The lake as a whole is classified as slightly mesotrophic (table 2). 


\subsection{Heart Lake}

Heart Lake is located about 6 miles $(10 \mathrm{~km})$ to the southeast of Lewis Lake (see figure 4). The lake is at elevation $7,450 \mathrm{ft}(2271 \mathrm{~m})$, has a surface area of about 2,500 acres $\left(10.1 \mathrm{~km}^{2}\right)$, has an approximate volume of 125,000 acre-ft $\left(0.15 \mathrm{~km}^{3}\right)$ and a maximum depth of $180 \mathrm{ft}(55 \mathrm{~m})$. Heart Lake's eastern bay is very shallow with depths less than $10 \mathrm{ft}(3 \mathrm{~m})$. The major inflowing streams are Witch and Beaver Creeks and the only outlet is the Heart River.

The results of sampling near Witch Creek and on the southwest side show Heart Lake as slightly mesotrophic, but slightly oligotrophic on the northwest side (see table 2). Although the lake is classified as slightly mesotrophic, if samples were taken on the east side, there may be a different classification.

\section{Mid-sized lakes in central Yellowstone Park}

Water samples were also taken at 4 lakes in central Yellowstone Park, namely, Cascade, Grebe, Ice and Wolf Lakes. Model evaluation led to the trophic classification or trophic state of each lake. The trophic results from each model and the overall averages are given in table 3 . The lakes are shown on figure 5 .

Table 3: $\quad$ Mid-sized lakes' trophic states according to the three models.

\begin{tabular}{|l|c|}
\hline \multicolumn{1}{|c|}{ Model } & Classification \\
\hline Cascade Lake & Strongly Mesotrophic \\
Carlson & Mesotrophic \\
Vollenweider & Strongly Mesotrophic \\
Larsen-Mercier & Strongly Mesotrophic \\
Cascade Lake Average & Mesotrophic \\
\hline Grebe Lake & Slightly Mesotrophic \\
Carlson & Strongly Mesotrophic \\
Vollenweider & Mesotrophic \\
Larsen-Mercier & \\
Grebe Lake Average & Slightly Mesotrophic \\
Ice Lake & Mesotrophic \\
Carlson & Slightly Eutrophic \\
Vollenweider & Mesotrophic \\
Larsen-Mercier & \\
Ice Lake Average & Mesotrophic \\
\hline Wolf Lake & Mesotrophic \\
Carlson & Slightly Eutrophic \\
Vollenweider & Strongly Mesotrophic \\
Larsen-Mercier & \\
Wolf Lake Average &
\end{tabular}




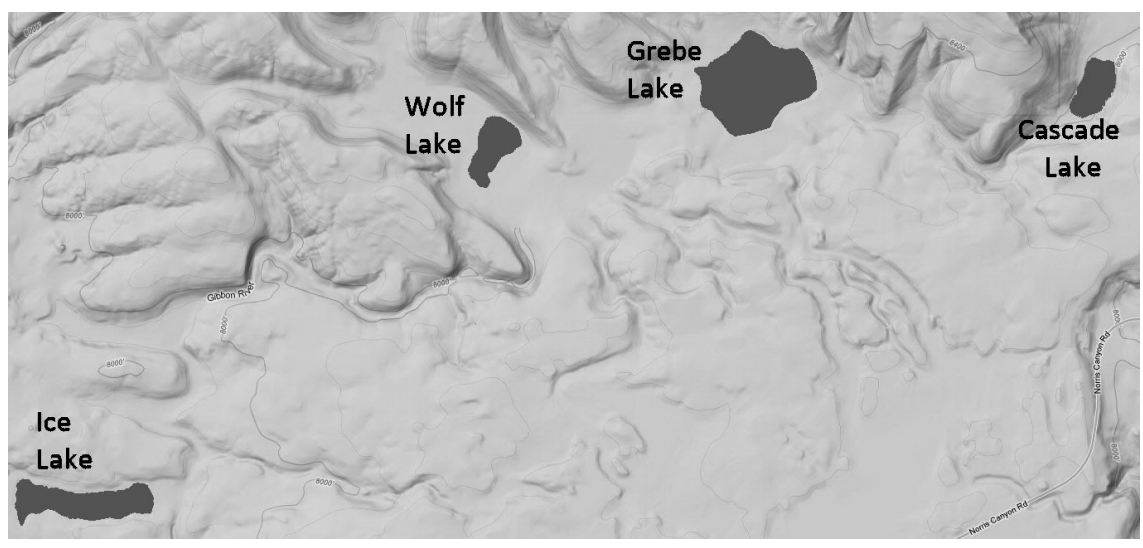

Figure 5: $\quad$ Map of mid-sized lakes in central Yellowstone Park.

\subsection{Summary}

Grebe Lake, as mesotrophic, appears to be in good trophic condition. Ice Lake also appears to be in good condition, based mainly on the Carlson Model and minimizing the Larsen-Mercier results. There is some concern for Cascade and Wolf Lakes as strongly mesotrophic. While trophic states varied from month to month, the water quality of the lakes, as measured by the trophic state, is generally good. Total nitrogen was also measured in these lakes and while the nitrogen concentrations were near or below the detection limit, the lakes appear to be on the border of being nitrogen limited or phosphorus limited. It will be very useful to compare these results with future studies in order to determine the effects of the significant human interaction on these lakes.

\section{Small lakes in northwestern Yellowstone Park}

Finally, this paper presents the results for other small lakes in northwestern Yellowstone Park, namely, South Nymph Lake, Nymph Lake, South Twin Lake, North Twin Lake, Lake of the Woods, Beaver Lake, Swan Lake, Blacktail Pond, Harlequin Lake and Goose Lake (see figures 6 and 7). The trophic state of each lake from each model and the overall average classifications are given in table 4.

\subsection{Summary}

Nymph Lake, Lake of the Woods and Beaver Lake were classified strongly mesotrophic because of high in-lake total phosphorus, and should be of concern. The eutrophication of these three lakes is less severe if they are not phosphoruslimited. However, Beaver Lake has almost gone away. Classifications of Lake of the Woods and Goose Lake were determined from only one sample, so they may need further study to determine if there is concern. The trophic states of the remainder of the lakes are based on several samples and are not of concern. 
Table 4: Small west lakes' trophic states according to each of the three models.

\begin{tabular}{|c|c|}
\hline Model & Classification \\
\hline $\begin{array}{c}\text { South Nymph Lake } \\
\text { Carlson } \\
\text { Vollenweider } \\
\text { Larsen-Mercier } \\
\text { South Nymph Lake Average }\end{array}$ & $\begin{array}{l}\text { Slightly Mesotrophic } \\
\text { Slightly Eutrophic } \\
\text { Slightly Eutrophic } \\
\text { Mesotrophic }\end{array}$ \\
\hline $\begin{array}{c}\text { Nymph Lake } \\
\text { Carlson } \\
\text { Vollenweider } \\
\text { Larsen-Mercier } \\
\text { Nymph Lake Average }\end{array}$ & $\begin{array}{l}\text { Slightly Eutrophic } \\
\text { Mesotrophic } \\
\text { Strongly Mesotrophic } \\
\text { Strongly Mesotrophic }\end{array}$ \\
\hline $\begin{array}{c}\text { South Twin Lake } \\
\text { Carlson } \\
\text { Vollenweider } \\
\text { Larsen-Mercier } \\
\text { South Twin Lake Average }\end{array}$ & $\begin{array}{l}\text { Slightly Oligotrophic } \\
\text { Slightly Oligotrophic) } \\
\text { Slightly Mesotrophic } \\
\text { Slightly Mesotrophic } \\
\end{array}$ \\
\hline $\begin{array}{c}\text { North Twin Lake } \\
\text { Carlson } \\
\text { Vollenweider } \\
\text { Larsen-Mercier } \\
\text { North Twin Lake Average } \\
\end{array}$ & $\begin{array}{c}\text { Slightly Mesotrophic } \\
\text { Strongly Eutrophic } \\
\text { Slightly Mesotrophic } \\
\text { Mesotrophic }\end{array}$ \\
\hline $\begin{array}{c}\text { Lake of the Woods } \\
\text { Carlson } \\
\text { Lake of the Woods Average }\end{array}$ & $\begin{array}{l}\text { Strongly Mesotrophic } \\
\text { Strongly Mesotrophic }\end{array}$ \\
\hline $\begin{array}{c}\text { Beaver Lake } \\
\text { Carlson } \\
\text { Vollenweider } \\
\text { Larsen-Mercier } \\
\text { Beaver Lake Average }\end{array}$ & $\begin{array}{l}\text { Slightly Mesotrophic } \\
\text { Eutrophic } \\
\text { Eutrophic } \\
\text { Strongly Mesotrophic }\end{array}$ \\
\hline $\begin{array}{c}\text { Swan Lake } \\
\text { Carlson } \\
\text { Swan Lake Average } \\
\end{array}$ & $\begin{array}{l}\text { Mesotrophic } \\
\text { Mesotrophic }\end{array}$ \\
\hline $\begin{array}{c}\text { Blacktail Pond } \\
\text { Carlson } \\
\text { Vollenweider } \\
\text { Larsen-Mercier } \\
\text { Blacktail Pond Average }\end{array}$ & $\begin{array}{c}\text { Slightly Mesotrophic } \\
\text { Strongly Mesotrophic } \\
\text { Slightly Eutrophic } \\
\text { Mesotrophic }\end{array}$ \\
\hline $\begin{array}{c}\text { Harlequin Lake (south of maps) } \\
\text { Carlson } \\
\text { Harlequin Lake Average }\end{array}$ & $\begin{array}{l}\text { Slightly Mesotrophic } \\
\text { Slightly Mesotrophic }\end{array}$ \\
\hline $\begin{array}{c}\text { Goose Lake (south of maps) } \\
\text { Carlson } \\
\text { Vollenweider } \\
\text { Larsen-Mercier } \\
\text { Goose Lake Average }\end{array}$ & $\begin{array}{l}\text { Oligotrophic } \\
\text { Strongly Mesotrophic } \\
\text { Strongly Mesotrophic } \\
\text { Slightly Mesotrophic }\end{array}$ \\
\hline
\end{tabular}


154 Water Pollution X

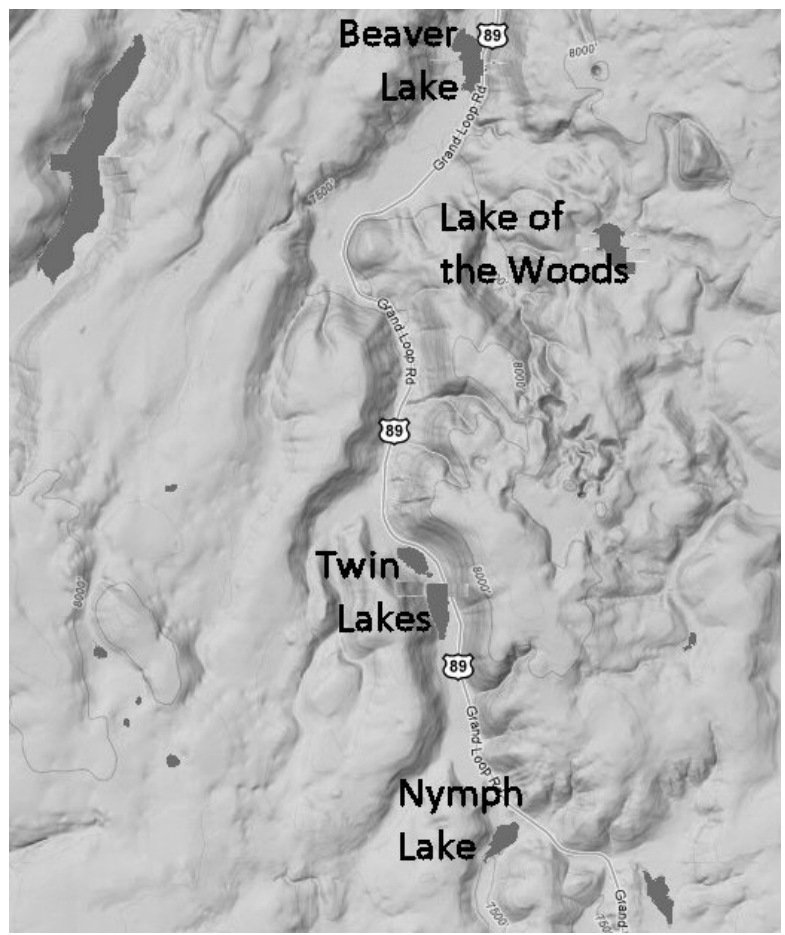

Figure 6: $\quad$ Map of small lakes in west Yellowstone Park.

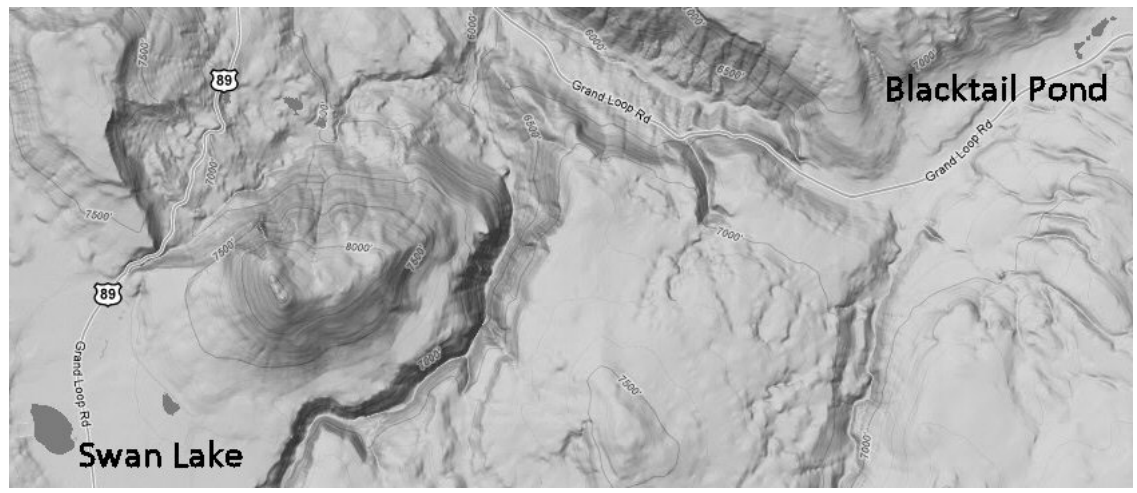

Figure 7: $\quad$ Map of small lakes in north Yellowstone Park.

\section{References}

[1] Chapra, S.C., Surface Water-Quality Modeling, McGraw-Hill, New York, 1997.

[2] Tchobanoglous, G. \& Schroeder, E., Water Quality, Addison-Wesley, 1985. 
[3] North American Lake Management Society (NALMS), Managing lakes and reservoirs, Terrene Institute, 2001.

[4] Environmental Protection Agency, Volunteer lake monitoring, JT\&A, 1991.

[5] Harper, D., Eutrophication of Freshwater, Chapman and Hall, New York, pp. 36-53, 1992.

[6] Correll, D.L., The role of phosphorus in the eutrophication of receiving waters, Journal of Environmental Quality, 27(2), pp. 261-266, 1998.

[7] Carlson, R.E., Trophic state index for lakes, Limnology and Oceanography, 22(2), pp. 361-369, 1977.

[8] Vollenweider, R.A., Fundamentals of the eutrophication of lakes and flowing water, with reference to $\mathrm{N}$ and $\mathrm{P}$ as factors in eutrophication, Technical Report OECH, Paris, France, DAS/CSI/68.27, 1968.

[9] Larsen, D.P. \& Mercier, H.T. Mercier, Lake phosphorus loading graphs: an alternative, Working Paper No. 174, Pacific Northwest Environmental Research Lab, EPA, Corvallis, Oregon, 1975. 